\title{
Kajian Peningkatan Akurasi Matriks Asal-Tujuan yang Dihasilkan dari Data Arus Lalulintas pada Kondisi Keseimbangan
}

\author{
Ofyar Z. Tamin ${ }^{1}$ \& Rusmadi Suyuti ${ }^{2}$ \\ ${ }^{1}$ KK Rekayasa Transportasi, Institut Teknologi Bandung \\ ${ }^{2}$ Staf Peneliti Direktorat Teknologi Transportasi, Badan Pengkajian dan Penerapan
}

Teknologi (BPPT)

\begin{abstract}
Abstrak. Informasi kondisi arus lalulintas sangat berguna pagi pengguna jalan karena pengguna jalan tersebut dapat memilih dan menentukan rute perjalanan terbaik yang akan dilaluinya sebelum melakukan perjalanan. Penelitian ini bertujuan akhir untuk mengembangkan sistem informasi arus lalulintas bagi pengguna jalan untuk wilayah Kota Bandung, yang dikembangkan menggunakan data arus lalulintas secara waktu nyata. Masukan utama yang diperlukan untuk mengembangkan sistem informasi tersebut adalah Matriks Asal-Tujuan (MAT) yang dikembangkan berdasarkan informasi arus lalulintas. Pada penelitian tahap ini telah ditinjau beberapa faktor yang berpengaruh terhadap peningkatan akurasi MAT yang dihasilkan dari data arus lalulintas, dimana model Gravity (GR) digunakan sebagai model sebaran pergerakan. Jenis metode estimasi yang akan ditinjau pengaruhnya adalah: Kuadrat-Terkecil (KT), Kemiripan-Maksimum (KM), Inferensi-Bayes (IB), dan Entropi-Maksimum (EM). Sedangkan model pemilihan rute yang akan ditinjau pengaruhnya adalah model all-or-nothing dan keseimbangan. Hasil penelitian menyimpulkan bahwa terdapat tingkat keakurasian yang cukup tinggi dalam proses estimasi MAT. Hal tersebut ditunjukkan berdasarkan nilai optimum dari fungsi tujuan serta hasil pengujian statistik.
\end{abstract}

Kata Kunci: distribusi perjalanan; matriks asal-tujuan; metode estimasi; pemilihan rute; pemodelan transportasi.

\begin{abstract}
The information of traffic volume condition is very useful to road users as it can be used by the road users in choosing and determining their best route. The final objective of this research is to develop traffic information system for road users in Bandung in a real-time basis. The main input needed to develop the traffic information system is Origin-Destination (OD) matrix which is estimated from traffic count data. In this stage of research, several influence factors of the estimated O-D matrices accuracy from traffic counts data have been reviewed. The model type of transport demand model was examined, namely: gravity (GR) model. Four different estimation methods were then developed to calibrate these models from traffic count data i.e: Least-Squares (LS), Maximum-Likelihood (ML), Maximum-Entropy (ME) and BayesInference (BI). In addition to all-or-nothing assignment, equilibrium assignment
\end{abstract}

Makalah diterima redaksi April 2006, revisi diterima tanggal 14 September 2006, diterima untuk diterbitkan tanggal 14 September 2006. 
model is used as types of the trip assignment methods. Based on several statistical tests and optimum value of the objective function, the methods are found to perform satisfactorily with the high accuracy in the process of matrix estimation.

Keywords: estimation method; origin-destination matrix; transportation model; trip assignment; trip distribution.

\section{Pendahuluan}

Kemacetan lalulintas yang sering terjadi pada saat jam sibuk merupakan salah satu masalah transportasi yang banyak dijumpai khususnya di kota-kota besar. Salah satu penyebab terjadinya kemacetan lalulintas tersebut adalah tidak seimbangnya volume lalulintas di ruas jalan dibandingkan dengan kapasitas ruas jalan tersebut. Hal tersebut dapat terjadi akibat tidak adanya informasi tentang kondisi volume lalulintas pada suatu ruas jalan. Jika informasi kondisi arus lalulintas dapat diketahui sebelum pengguna jalan melakukan perjalanan, maka pengguna jalan tersebut dapat memilih dan menentukan rute perjalanan terbaik (best route) yang akan dilaluinya. Kriteria penetapan rute terbaik tersebut didasarkan pada nilai rasio volume dan kapasitas $(\mathrm{V} / \mathrm{C}$ ratio) serta kecepatan rata-rata kendaraan pada tiap ruas yang ada di dalam wilayah studi.

Penelitian ini mempunyai tujuan akhir mengembangkan sistem informasi arus lalulintas bagi pengguna jalan untuk wilayah Kota Bandung dengan menggunakan data arus lalulintas secara waktu nyata (real time). Masukan utama yang diperlukan adalah Matriks Asal-Tujuan (MAT) dinamis yang dikembangkan berdasarkan informasi arus lalulintas (real time) yang diperoleh dari sistem pengaturan lalulintas secara terkoordinasi (sistem ATCS).

MAT merupakan informasi dasar yang sangat dibutuhkan dalam berbagai kebijakan di sektor transportasi, salah satu diantaranya adalah untuk menentukan rute yang akan dipilih pengemudi. Metoda konvensional (home interview dan roadside interview) untuk mendapatkan MAT membutuhkan biaya sangat mahal, waktu proses sangat lama, dan tenaga kerja sangat banyak.

Penelitian terdahulu yang telah dilakukan oleh pengusul dalam studi doktoralnya [1] memungkinkan MAT didapat dengan hanya menggunakan data arus lalulintas yang notabene sangat mudah dan murah mendapatkannya (akurasi MAT dapat mencapai 97\% dan butuh waktu hanya sekitar 2-3 menit setelah arus lalulintas didapatkan sehingga biaya dapat ditekan menjadi hanya sekitar $4 \%$ biaya metoda konvensional). Akan tetapi, pada saat itu, pengusul masih menggunakan data arus lalulintas statis yang didapat dari hasil survei primer lapangan. 
Sistem Pengaturan Lampu Lalulintas Terkoordinasi (Area Traffic Control System/ATCS) yang telah dioperasikan pada beberapa kota di Indonesia (Jakarta, Bandung, dan Surabaya) memungkinkan kita mendapatkan informasi arus lalulintas secara otomatis dan real time (di Kotamadya Bandung sudah beroperasi sejak tahun 1997). Teknologi transfer informasi (internet) memungkinkan kita mendapatkan informasi tersebut secara real time dengan biaya sangat murah.

Dengan menggunakan informasi real time tersebut, metode penelitian ini dilakukan melalui serangkaian simulasi pada suatu sistem pemodelan yang menghasilkan MAT secara dinamis dan real time pula. Keluaran MAT real time tersebut termasuk beberapa aplikasinya akan disajikan dalam Website yang dirancang khusus sesuai dengan kebutuhan (baik numerik maupun grafis) sehingga dapat langsung diakses dan digunakan oleh para pengguna (Bappeda, DLLAJ, Konsultan, Bina Marga, Departemen Perhubungan, Polantas, dan instansi terkait lainnya) melalui fasilitas internet.

Salah satu aplikasi yang bisa diperoleh dari website tersebut adalah berupa petunjuk arah lalulintas (road guidance). Petunjuk arah tersebut dapat berguna bagi pengemudi atau pengguna jalan lainnya yang akan melakukan perjalanan dari tempat asal menuju ke tempat tujuannya. Informasi yang bisa didapat dari website diantaranya adalah rute terpendek (shortest path) yang bisa dilalui beserta perkiraan lama waktu tempuhnya (travel time). Di masa mendatang informasi tersebut juga dapat dikembangkan menjadi suatu alat yang dapat diinstall di suatu kendaraan, sehingga dapat mempermudah pengguna kendaraan tersebut untuk menentukan rute yang akan dilaluinya untuk menuju ke tempat tujuan perjalanannya.

\section{$2 \quad$ Metodologi}

Proses pengembangan sistem informasi arus lalulintas dengan menggunakan MAT dinamis dapat dijelaskan dengan Gambar 1. Informasi arus lalulintas secara real time dapat diakses langsung dari pusat kontrol proyek ATCS melalui fasilitas internet. Sebelum informasi tersebut digunakan dalam proses estimasi MAT, maka beberapa proses harus dilakukan agar informasi arus lalulintas tersebut dapat digunakan, misalnya seperti: penetapan format, pembuatan data base sistem zona dan sistem jaringan dari daerah studi, dan lain-lain. Setelah proses tersebut, maka informasi arus lalulintas baru dapat digunakan untuk menghasilkan MAT. Keluaran MAT real time harus diolah sedemikian rupa sesuai kebutuhan sehingga dapat bermanfaat bagi pengguna. Hasil pengolahan MAT tersebut beserta beberapa aplikasinya akan disajikan dalam Website yang akan dirancang khusus dalam penelitian ini sesuai dengan kebutuhan (baik dalam bentuk numerik maupun grafis). 


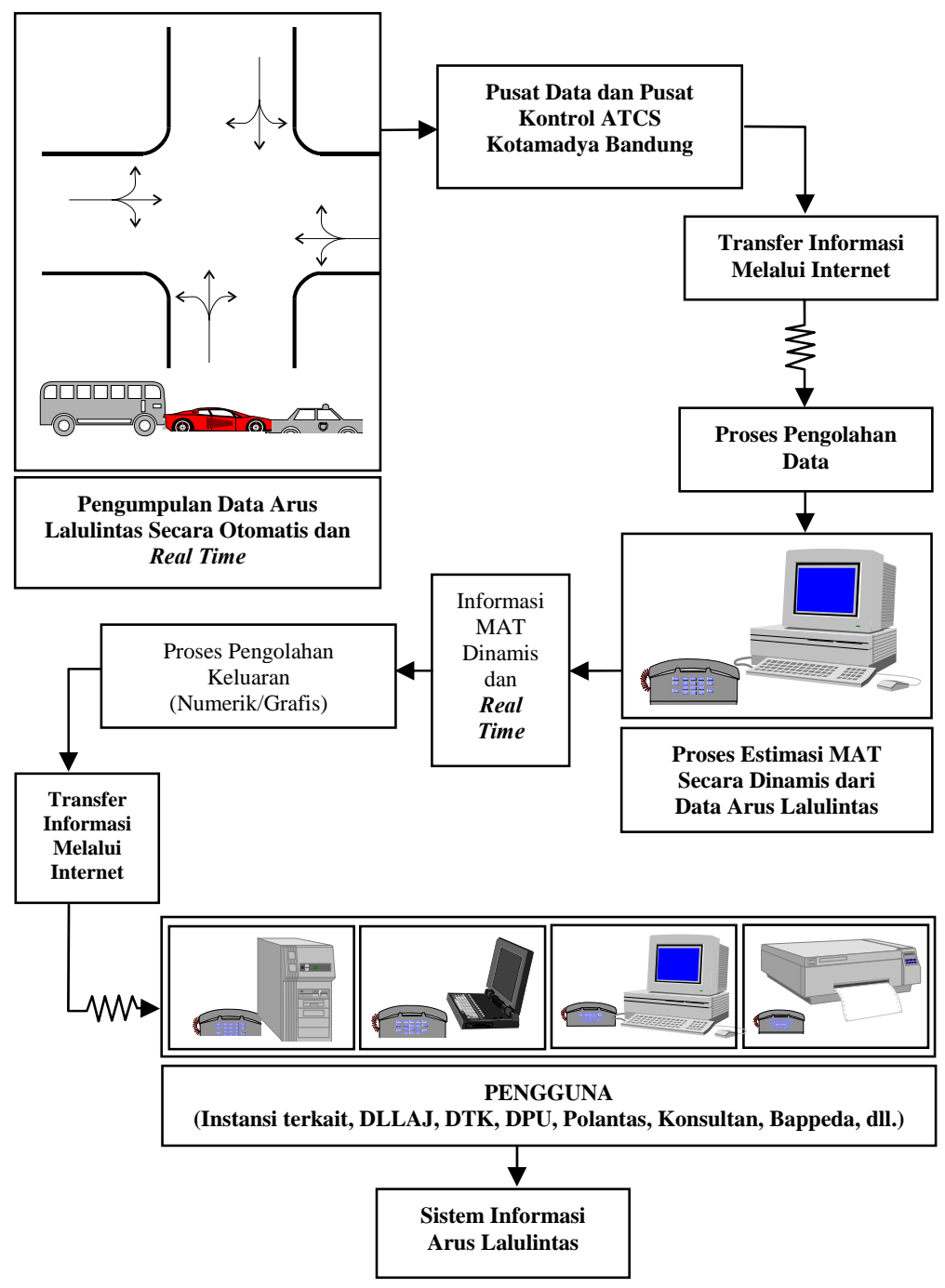

Gambar 1 Proses pengembangan sistem informasi arus lalulintas menggunakan MAT dinamis. Sumber: Tamin, O.Z., et al [2].

Informasi MAT ini sangat dibutuhkan dan sangat membantu berbagai pihak, misalnya: instansi, departemen, konsultan, pengguna jalan, penentu kebijaksanaan, lembaga baik kelompok maupun perorangan yang terkait dengan sektor transportasi. Informasi mengenai kebutuhan pergerakan dalam bentuk MAT yang paling terkini dan berpola dinamis (real time) bisa didapatkan dengan biaya yang sangat murah dan waktu yang sangat cepat. Dengan kata lain, kita bisa mendapatkan informasi MAT untuk Kota Bandung untuk kondisi 5 menit yang lalu dengan biaya yang sangat murah serta dengan tingkat akurasi 
yang sangat tinggi sehingga ketergantungan dengan data MAT tahun 1992 ataupun tahun 1995 sudah dapat kita tinggalkan.

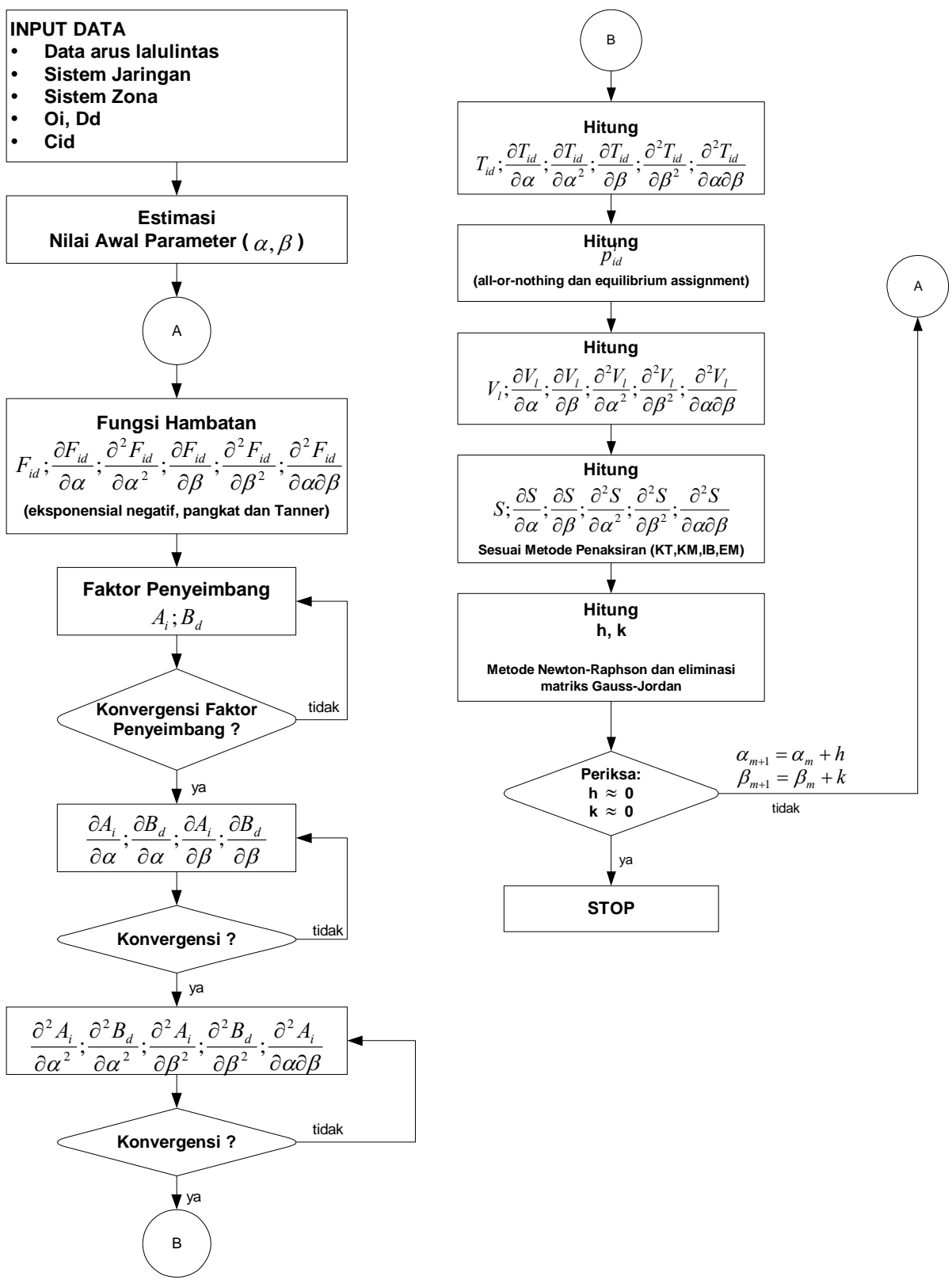

Gambar 2 Proses Kalibrasi dengan Menggunakan Model Gravity. 
Metode penelitian untuk tahap awal diarahkan untuk meninjau faktor-faktor yang berpengaruh terhadap tingkat keakurasian MAT yang dihasilkan dari informasi arus lalulintas. Model kebutuhan akan transportasi yang digunakan dalam penelitian ini adalah model Gravity (GR). Sedangkan faktor-faktor pengaruh yang akan ditinjau adalah sebagai berikut:

- Pengaruh metode estimasi untuk mengkalibrasi parameter model kebutuhan transportasi. Metode estimasi yang akan ditinjau adalah meliputi: KuadratTerkecil (KT), Kemiripan-Maksimum (KM), Inferensi-Bayes (IB) dan Entropi-Maksimum (EM).

- Pengaruh metode pemilihan rute. Metode pemilihan rute yang akan ditinjau adalah metode all-or-nothing dan metode pemilihan rute keseimbangan (equilibrium assignment)

Proses kalibrasi untuk estimasi Matriks Asal-Tujuan dengan menggunakan data arus lalulintas, jika digunakan model Gravity (GR) adalah ditunjukkan pada Gambar 2.

\section{$3 \quad$ Metoda Estimasi}

Tamin $[3,4]$ telah mengembangkan beberapa tipe metoda estimasi yang dapat digunakan sebagai berikut:

- Metoda Estimasi Kuadrat-Terkecil atau Kuadrat-Terkecil-Berbobot (KT atau KTB)

- Metoda Estimasi Kemiripan-Maksimum (KM)

- Metoda Estimasi Inferensi-Bayes (IB)

- Metoda Estimasi Entropi-Maksimum (EM)

\subsection{Metode Estimasi Kuadrat-Terkecil atau Kuadrat-terkecil- berbobot (KT atau KTB)}

Metode estimasi ini mencoba mengkalibrasi parameter model transportasi yang tidak diketahui sehingga meminimumkan jumlah perbedaan kuadrat antara arus lalulintas hasil estimasi dan hasil pengamatan. Secara matematis, masalah kalibrasi dari metode penaksiran Kuadrat-Terkecil dapat dinyatakan sebagai berikut dengan $\dddot{\boldsymbol{V}}_{\boldsymbol{l}}=1$ untuk KT atau $\dddot{\boldsymbol{V}}_{\boldsymbol{l}}=\hat{\boldsymbol{V}}_{\boldsymbol{l}}$ untuk Kuadrat-TerkecilBerbobot (KTB): 


$$
\text { Minimumkan } S=\sum_{l=1}^{L}\left[\frac{\left(V_{l}-\hat{V}_{l}\right)^{2}}{\ddot{V}_{l}}\right]
$$

dimana: $\boldsymbol{V}_{\boldsymbol{l}}=$ jumlah arus di ruas hasil estimasi; $\hat{\boldsymbol{V}}_{\boldsymbol{l}}=$ jumlah arus di ruas hasil pengamatan.

\subsection{Metode Estimasi Kemungkinan-Maksimum (KM)}

Tamin $[3,4]$ juga sudah membangun metode estimasi yang mencoba untuk memaksimumkan kemungkinan yang tercantum pada persamaan di bawah. Kerangka kerja dari metode estimasi KM adalah berupa pemilihan hipotesis $\mathrm{H}$ yang memaksimumkan persamaan di bawah dengan batasan tertentu, yang nantinya menghasilkan sebaran $\boldsymbol{V}_{l}$ yang paling sesuai dengan data hasil survei $\left(\hat{V}_{l}\right)$. Fungsi obyektif dari kerangka kerja ini adalah:

$$
\begin{array}{cc}
\text { Maksimumkan } & L=c \cdot \prod_{l} p_{l}^{\hat{V}_{l}} \\
\text { dengan batasan } & \sum_{l} V_{l}-\hat{V}_{T}=0
\end{array}
$$

dimana: $\hat{V}_{T}=$ arus total lalu lintas hasil pengamatan

$$
\boldsymbol{c} \text { = konstanta, dimana } \boldsymbol{p}_{l}=\frac{\boldsymbol{V}_{l}}{\hat{\boldsymbol{V}}_{\boldsymbol{T}}}
$$

\subsection{Metode Estimasi Inferensi-Bayes (IB)}

Tamin [4] menyebutkan, metode ini menggunakan suatu probabilitas subyektif untuk mengukur tingkat kepercayaan tentang suatu keadaan. Pada metode ini, pertimbangan subyektif berdasarkan intuisi, pengalaman atau informasi yang tidak langsung, secara sistematis digabungkan dengan data pengamatan untuk mendapatkan suatu taksiran yang seimbang. Fungsi obyektif dari metode estimasi Inferensi-Bayes (IB) adalah :

$$
\text { Maksimumkan } \operatorname{IB}\left(\tau_{l} V_{l}\right)=\sum_{l=1}^{\mathrm{L}}\left(\hat{V}_{l} \log _{e}\left(\sum_{i}^{\mathrm{N}} \sum_{d}^{\mathrm{N}} T_{i d} \cdot p_{i d}^{l}\right)\right)
$$




\subsection{Metode Estimasi Entropi-Maksimum (EM)}

Menurut Tamin [4], metode estimasi entropi maksimum dikembangkan dari analogi fisika yaitu konsep tentang metode penyusunan mikro suatu sistem tertentu misalnya molekul gas. Pada model sebaran pergerakan diasumsikan bahwa pergerakan yang terjadi seperti molekul gas yang dapat bergerak bebas, sehingga menghasilkan sebaran maksimum. Dalam hal model sebaran perjalanan, pergerakan yang terjadi dapat dianggap sebagai molekul gas yang dapat bergerak bebas sehingga sebarannya maksimum atau distribusinya merata. Hal tersebut merupakan konsep dasar dari pengembangan metode estimasi entropi maksimum. Fungsi tujuan dari model estimasi entropi maksimum adalah sebagai berikut:

Maksimumkan

$$
\mathrm{E}_{1}=-\sum_{l=1}^{\mathrm{L}}\left[\sum_{i=1}^{\mathrm{N}} \sum_{d=1}^{\mathrm{N}} T_{i d} \cdot \boldsymbol{p}_{i d}^{l} \cdot \log _{e}\left(\frac{\sum_{i=1}^{\mathrm{N}} \sum_{d=1}^{\mathrm{N}} T_{i d} \cdot p_{i d}^{l}}{\hat{V}_{l}}\right)-\left(\sum_{i=1}^{\mathrm{N}} \sum_{d=1}^{\mathrm{N}} T_{i d} \cdot p_{i d}^{l}\right)+\hat{V}_{l}\right]
$$

\section{$4 \quad$ Hasil Riset dan Pembahasan}

Proses analisis dilakukan dengan meninjau faktor-faktor yang berpengaruh terhadap peningkatan akurasi MAT yang dihasilkan dari data arus lalulintas.

\subsection{Pengaruh Jenis Model Gravity (GR)}

Jenis model gravity yang ditinjau dalam penelitian ini adalah model gravity dengan batasan-bangkitan, batasan-tarikan dan batasan-bangkitan-tarikan.

Model batasan-bangkitan dihasilkan dengan menetapkan nilai $B_{d}=1$, untuk semua $d$ untuk menghilangkan batasan tarikan pergerakan $\left(D_{d}\right)$. Selanjutnya dengan menetapkan nilai $A_{i}=1$, untuk semua $i$ untuk menghilangkan batasan bangkitan pergerakan $\left(O_{i}\right)$, maka model batasan-tarikan bisa dihasilkan. Sedangkan model GR dengan-batasan-bangkitan-tarikan dihasilkan dengan melakukan iterasi terhadap nilai $A_{i}$ dan $B_{d}$.

Hasil estimasi parameter model kebutuhan transportasi yang dihasilkan untuk berbagai jenis model GR adalah ditunjukkan pada Tabel 1. Proses tersebut dilakukan dengan metode estimasi Kuadrat-Terkecil-Berbobot (KTB), fungsi hambatan eksponensial-negatif dan metode pemilihan rute keseimbangan (equilibrium assignment). 
Tabel 1 Hasil estimasi parameter model transportasi menurut jenis model GR.

\begin{tabular}{lccr}
\hline \multirow{2}{*}{ No } & Model Gravity & \multicolumn{2}{c}{ Fungsi Eksponensial-Negatif } \\
\cline { 3 - 4 } 1 & Batasan-bangkitan & 0,117298 & 167710,515 \\
2 & Batasan-tarikan & 0,146357 & 245954,062 \\
3 & Batasan-bangkitan-tarikan & 0,060252 & 58142,598 \\
\hline
\end{tabular}

Dari Tabel 1 dapat dilihat bahwa dari ketiga jenis model GR (batasanbangkitan, batasan-tarikan dan batasan-bangkitan-tarikan), model GR dengan batasan-bangkitan-tarikan menghasilkan tingkat keakurasian yang paling baik dibandingkan jenis model GR lainnya. Hal tersebut ditunjukkan berdasarkan nilai minimum dari fungsi tujuan dari metode estimasi KTB, dimana jenis batasan-bangkitan-tarikan nilainya paling kecil. Setelah model batasan bangkitan-tarikan, urutan selanjutnya adalah model batasan-bangkitan. Model ini kinerjanya lebih baik dibandingkan model batasan-tarikan.

Dari hasil estimasi, penggunaan nilai awal yang berbeda pada proses iterasi akan selalu menghasilkan nilai estimasi yang relatif sama. Kalaupun terjadi perbedaan, perbedaan tersebut nilainya sangat kecil sehingga dapat diabaikan. Dari sini dapat disimpulkan bahwa metode estimasi tersebut selalu menghasilkan satu solusi tunggal yang sama nilainya (a unique solution). Perbedaan yang terjadi hanya pada cepat atau lambatnya konvergensi tercapai. Secara umum dapat dikatakan bahwa semakin jauh nilai awal dari nilai yang dituju, akan semakin lama waktu yang dibutuhkan untuk mencapai konvergensi. Hasil uji statistik untuk tiap-tiap jenis model GR adalah seperti ditunjukkan pada Tabel 2 untuk tingkat MAT.

Tabel 2 Indikator uji statistik untuk masing-masing model GR dengan menggunakan metode estimasi Kuadrat-Terkecil untuk tingkat MAT.

\begin{tabular}{|c|c|c|c|c|}
\hline \multirow[b]{2}{*}{ No } & \multirow[b]{2}{*}{$\begin{array}{c}\text { Indikator Uji } \\
\text { Statistik }\end{array}$} & \multicolumn{3}{|c|}{ Fungsi Eksponensial-Negatif } \\
\hline & & $\begin{array}{c}\text { Batasan- } \\
\text { Bangkitan }\end{array}$ & $\begin{array}{l}\text { Batasan- } \\
\text { Tarikan }\end{array}$ & $\begin{array}{c}\text { Batasan- } \\
\text { Bangkitan-Tarikan }\end{array}$ \\
\hline 1 & RMSE & 4,593072 & 5,744880 & 4,332783 \\
\hline 2 & \%RMSE (\%) & 77,198669 & 96,557853 & 72,823829 \\
\hline 3 & MAE & 2,360288 & 2,901026 & 2,132322 \\
\hline 4 & NMAE (\%) & 39,670856 & 48,759395 & 35,839282 \\
\hline 5 & $\mathbf{R}^{2}$ & 0,722734 & 0,566237 & 0,753269 \\
\hline 6 & $\mathbf{S R}^{2}$ & 0,650865 & 0,491824 & 0,759040 \\
\hline
\end{tabular}


Dari Tabel 2, dapat dilihat bahwa ditinjau dari indikator uji statistik untuk tingkat MAT, model GR dengan batasan-bangkitan-tarikan (DCGR) memberikan tingkat kinerja yang terbaik.

\subsection{Pengaruh Fungsi Hambatan}

Salah satu parameter penting dalam menentukan MAT adalah fungsi hambatan atau $f\left(C_{i d}\right)$. Hal yang terpenting untuk diketahui adalah $f\left(C_{i d}\right)$ harus dianggap sebagai ukuran aksesibilitas (kemudahan) antara zona $i$ dengan zona $d$. Hyman [5] menyarankan tiga jenis fungsi hambatan yang dapat digunakan dalam model GR, yaitu fungsi eksponensial-negatif, fungsi pangkat, fungsi Tanner (gabungan fungsi eksponensial-negatif dan fungsi pangkat).

Tabel 3 Hasil estimasi parameter model transportasi menurut jenis fungsi hambatan.

\begin{tabular}{ccrrr}
\hline \multirow{2}{*}{ No } & \multirow{2}{*}{ Fungsi Hambatan } & \multicolumn{3}{c}{ Batasan-Bangkitan-Tarikan } \\
\cline { 3 - 5 } & & $\boldsymbol{\alpha}$ & $\boldsymbol{\beta}$ & Fungsi Tujuan \\
\hline 1 & Eksponensial-Negatif & - & 0,06025 & 58142,5 \\
2 & Pangkat & - & 0,72848 & 50267,9 \\
3 & Tanner & 0,959 & $-0,0212$ & 44839,2 \\
\hline
\end{tabular}

Hasil estimasi parameter model kebutuhan transportasi yang dihasilkan untuk berbagai jenis fungsi hambatan adalah ditunjukkan pada Tabel 3. Proses tersebut dilakukan dengan metode estimasi Kuadrat-Terkecil-Berbobot (KTB), jenis model batasan-bangkitan-tarikan dan metode pemilihan rute keseimbangan (equilibrium assignment).

Tabel 4 Indikator uji statistik untuk masing-masing fungsi hambatan untuk tingkat MAT.

\begin{tabular}{ccrrr}
\hline \multirow{2}{*}{ No } & \multirow{2}{*}{\begin{tabular}{c}
\multirow{2}{*}{ Sndikator Uji } \\
\cline { 3 - 5 }
\end{tabular}} & \multicolumn{3}{c}{ Model Batasan-Bangkitan-Tarikan } \\
\hline $\mathbf{1}$ & RMSE & $\begin{array}{c}\text { Fungsi Eksponensial- } \\
\text { Negatif }\end{array}$ & Fungsi Pangkat & Fungsi Tanner \\
$\mathbf{2}$ & \%RMSE (\%) & 4,332783 & 4,053458 & 4,013545 \\
$\mathbf{3}$ & $\mathbf{M A E}$ & 72,823829 & 68,129035 & 67,458198 \\
$\mathbf{4}$ & $\mathbf{N M A E ~ ( \% ) ~}$ & 2,132322 & 2,031995 & 2,023216 \\
$\mathbf{5}$ & $\mathbf{R}^{\mathbf{2}}$ & 35,839282 & 34,153026 & 34,005466 \\
$\mathbf{6}$ & $\mathbf{S R}^{\mathbf{2}}$ & 0,753269 & 0,784056 & 0,788287 \\
& & 0,759040 & 0,776553 & 0,779582 \\
\hline
\end{tabular}

Dari Tabel 3 dapat dilihat bahwa hasil perbandingan antara tiap jenis fungsi hambatan menunjukkan bahwa fungsi hambatan Tanner memberikan tingkat kinerja yang terbaik. Hal tersebut ditunjukkan berdasarkan nilai minimum dari fungsi tujuan dari metode estimasi KTB. Setelah fungsi Tanner, urutan terbaik 
selanjutnya adalah fungsi pangkat. Fungsi ini kinerjanya lebih baik dibandingkan dengan fungsi eksponensial-negatif.

Jika dikombinasikan dengan jenis model GR seperti telah dibahas sebelumnya, maka kinerja terbaik ditunjukkan oleh jenis model GR batasan-bangkitantarikan (DCGR) dengan fungsi hambatan Tanner. Hasil uji statistik untuk tiaptiap jenis fungsi hambatan adalah seperti ditunjukkan pada Tabel 4.

Dari Tabel 4, dapat dilihat bahwa ditinjau dari indikator uji statistik, maka model GR dengan fungsi Tanner yang dikombinasikan dengan model batasanbangkitan-tarikan memberikan tingkat kinerja yang terbaik.

\subsection{Pengaruh Metode Estimasi}

Banyak penelitian telah dilakukan terhadap aplikasi dari berbagai metode estimasi parameter untuk membangun suatu MAT dengan berbagai model sebaran pergerakan. Dalam penelitian ini, model sebaran pergerakan yang digunakan adalah model GR. Parameter yang akan diestimasi adalah parameter $\beta$. Selanjutnya akan dikembangkan aplikasi metode estimasi Kuadrat Terkecil (KT), Kuadrat Terkecil berbobot (KTB), Kemiripan Maksimum (KM), Inferensi Bayes (IB) dan Entropi Maksimum (EM) untuk memperoleh parameter $\beta$ pada model GR berdasarkan data arus lalulintas pada ruas jalan.

Metode estimasi KT dan KTB memiliki karakteristik yang serupa, demikian juga antara metode estimasi KM dan IB. Hal ini dapat disebabkan karena pendekatan yang dilakukan dalam metode estimasi KT sama dengan KTB, yaitu mengkalibrasi parameter yang tidak diketahui dengan meminimumkan deviasi antara arus lalulintas pengamatan dengan arus lalulintas hasil estimasi. Sedangkan pendekatan untuk mengkalibrasi parameter yang dilakukan dalam metode estimasi IB mirip dengan KM, yaitu didasari dengan memaksimumkan kemiripan antara data pengamatan dengan hasil estimasinya. Kedua metode tersebut mengasumsikan pergerakan yang terjadi mengikuti distribusi poisson. Metode estimasi EM menghasilkan pola yang berbeda karena pendekatan yang dilakukan adalah dengan mencari peluang yang paling maksimum yang terjadi dalam sebaran pergerakan. Penyelesaian dari metode-metode tersebut akan dilakukan dengan menggunakan Newton-Raphson yang dikombinasikan dengan metode eliminasi matriks Gauss-Jordan.

Hasil estimasi parameter model kebutuhan transportasi yang dihasilkan untuk berbagai jenis metode estimasi adalah ditunjukkan pada Tabel 5. Proses tersebut dilakukan dengan model GR dengan batasan-bangkitan-tarikan, fungsi hambatan eksponensial-negatif dan metode pemilihan rute keseimbangan (equilibrium assignment). Model batasan-bangkitan-tarikan dipilih karena 
berdasarkan hasil simulasi pada bagian sebelumnya, menunjukkan kinerja yang terbaik jika dibandingkan dengan model batasan-bangkitan maupun batasantarikan.

Tabel 5 Hasil estimasi parameter model transportasi menurut jenis metode estimasi pada kondisi model GR Batasan-Bangkitan-Tarikan dan pemilihan rute keseimbangan.

\begin{tabular}{cccr}
\hline \multirow{2}{*}{ No } & \multirow{2}{*}{ Metode Estimasi } & \multicolumn{2}{c}{ GR } \\
\cline { 3 - 4 } & & $\boldsymbol{\beta}$ & \multicolumn{1}{c}{ Fungsi Tujuan } \\
\hline 1 & Kuadrat-Terkecil (KT) & 0,060252 & 47349752,0000 \\
2 & Kuadrat-Terkecil-Berbobot (KTB) & 0,068619 & 62175,1445 \\
3 & Kemiripan-Maksimum (KM) & 0,067810 & 13279375,0000 \\
4 & Inferensi-Bayes (IB) & 0,059928 & 13284560,0000 \\
5 & Entropi-Maksimum (EM) & 0,063099 & $-24061,0330$ \\
\hline
\end{tabular}

Dari Tabel 5 dapat dilihat bahwa masing-masing metode estimasi menghasilkan parameter $\beta$ yang nilainya hampir sama antara satu metode dengan metode yang lainnya. Untuk menentukan tingkat kinerja tidak bisa menggunakan parameter nilai fungsi tujuan, karena metode mencari fungsi tujuan berbeda antara satu metode dengan metode lainnya. Sehingga penentuan tingkat kinerja didasarkan pada perbandingan nilai uji statistik untuk masing-masing metode estimasi.

Indikator uji statistik dimaksudkan untuk membandingkan kinerja masingmasing metode estimasi ditinjau dari indikator statistik yang dihasilkan. Pengujian ini dilakukan dengan membandingkan MAT hasil estimasi dengan MAT hasil observasi. Hasil uji statistik untuk tiap-tiap jenis metode estimasi untuk adalah seperti ditunjukkan pada Tabel 6.

Tabel 6 Indikator uji statistik untuk masing-masing metode estimasi dengan menggunakan model GR Batasan-Bangkitan-Tarikan untuk tingkat MAT.

\begin{tabular}{|c|c|c|c|c|c|c|}
\hline \multirow[b]{2}{*}{ No } & \multirow[b]{2}{*}{$\begin{array}{c}\text { Indikator Uji } \\
\text { Statistik }\end{array}$} & \multicolumn{5}{|c|}{ GR } \\
\hline & & $\begin{array}{c}\text { Kuadrat- } \\
\text { Terkecil } \\
\text { (KT) }\end{array}$ & $\begin{array}{c}\text { Kuadrat- } \\
\text { Terkecil- } \\
\text { Berbobot } \\
\text { (KTB) } \\
\end{array}$ & $\begin{array}{l}\text { Kemiripan- } \\
\text { Maksimum } \\
\text { (KM) }\end{array}$ & $\begin{array}{l}\text { Inferensi- } \\
\text { Bayes (IB) }\end{array}$ & $\begin{array}{l}\text { Entropi- } \\
\text { Maksimum } \\
\text { (EM) }\end{array}$ \\
\hline 1 & RMSE & 4,332783 & 4,276519 & 4,278709 & 4,336364 & 4,305590 \\
\hline 2 & \%RMSE (\%) & 72,823829 & 71,878158 & 71,914962 & 72,884017 & 72,366775 \\
\hline 3 & MAE & 2,132322 & 2,107042 & 2,108776 & 2,133564 & 2,122188 \\
\hline 4 & NMAE (\%) & 35,839282 & 35,414382 & 35,443523 & 35,860168 & 35,668964 \\
\hline 5 & $\mathbf{R}^{2}$ & 0,753269 & 0,759635 & 0,759389 & 0,752861 & 0,756356 \\
\hline 6 & $\mathrm{SR}^{2}$ & 0,759040 & 0,759238 & 0,759388 & 0,758955 & 0,759541 \\
\hline
\end{tabular}


Dari Tabel 6, terlihat bahwa ditinjau dari indikator uji statistik, maka metode estimasi yang mempunyai kinerja yang terbaik adalah metode estimasi KTB. Setelah itu, yang mempunyai tingkat keakurasian yang cukup tinggi juga adalah metode estimasi KM.

Meskipun demikian perbedaan antara satu metode estimasi dengan metode estimasi lainnya sangat kecil. Hal itu terbukti ketika digunakan fungsi hambatan eksponensial-negatif, metode estimasi apapun yang digunakan, selalu menghasilkan koefisien determinasi $\left(\mathrm{R}^{2}\right)$ yang relatif sama, yaitu antara 0,75 dan 0,76. Sehingga dapat disimpulkan bahwa semua metode menghasilkan tingkat akurasi yang relatif sama.

Berdasarkan faktor-faktor pengaruh yang telah disebutkan sebelumnya, kombinasi yang terbaik dalam melakukan estimasi parameter model kebutuhan transportasi adalah menggunakan: model batasan-bangkitan-tarikan, fungsi hambatan Tanner dan metode estimasi KTB. Dalam hal ini metode pemilihan rute yang digunakan adalah pemilihan rute keseimbangan (equilibrium assignment). Pada bagian selanjutnya akan ditinjau pengaruh metode pemilihan rute all-or-nothing.

\subsection{Pengaruh Metode Pemilihan Rute}

Asumsi dasar yang digunakan pada pengembangan model estimasi MAT dengan menggunakan data arus lalulintas adalah bahwa pergerakan arus lalulintas dari suatu zona ke zona lainnya pada dasarnya dapat direpresentasikan pada besarnya arus lalulintas pada suatu ruas jalan yang sangat tergantung pada besarnya proporsi pergerakan yang terjadi antara kedua zona tersebut yang menggunakan ruas tersebut sebagai bagian dari rute terbaiknya. Besarnya proporsi pergerakan tersebut sangat tergantung pada jenis model pemilihan rute yang digunakan. Untuk penelitian disertasi ini, jenis pemilihan rute yang ditinjau adalah pemilihan rute all-or-nothing dan pemilihan rute keseimbangan.

Tabel 7 Hasil estimasi parameter model transportasi menurut jenis pemilihan rute.

\begin{tabular}{cc|cr}
\hline \multirow{2}{*}{ No } & \multirow{2}{*}{ Metode Pemilihan Rute } & \multicolumn{2}{|c}{ GR } \\
\cline { 3 - 4 } & Keseimbangan & $\boldsymbol{\beta}$ & \multicolumn{1}{c}{ Fungsi Tujuan } \\
\hline 1 & All-Or-Nothing & 0,068619 & 62175,14 \\
2 & & 0,127845 & 144568,33 \\
\hline
\end{tabular}

Hasil estimasi parameter model kebutuhan transportasi yang dihasilkan pada kondisi pemilihan rute keseimbangan (equilibrium assignment) dan pemilihan rute all-or-nothing untuk berbagai jenis metode estimasi adalah ditunjukkan pada Tabel 7. Proses tersebut dilakukan dengan model GR dengan batasan- 
bangkitan-tarikan, fungsi hambatan eksponensial-negatif serta metode estimasi KTB.

Dari Tabel 7 dapat dilihat bahwa jika dibandingkan dari nilai fungsi tujuan, maka penggunaan metode pemilihan rute keseimbangan jauh lebih baik dari pada penggunaan metode pemilihan rute all-or-nothing.

Tabel 8 Indikator uji statistik untuk masing-masing metode pemilihan rute.

\begin{tabular}{lc|rr}
\hline \multirow{2}{*}{ No } & \multirow{2}{*}{$\begin{array}{c}\text { Indikator Uji } \\
\text { Statistik }\end{array}$} & \multicolumn{2}{|c}{ GR } \\
\cline { 3 - 4 } & Kemilihan Rute & $\begin{array}{c}\text { Pemilihan Rute } \\
\text { All-Or-Nothing }\end{array}$ \\
\hline 1 & RMSE & 4,276519 & 6,049265 \\
2 & \%RMSE (\%) & 71,878158 & 101,673820 \\
3 & MAE & 2,107042 & 2,430328 \\
4 & NMAE (\%) & 35,414382 & 40,848056 \\
5 & $\mathbf{R}^{2}$ & 0,759635 & 0,519054 \\
6 & SR $^{2}$ & 0,759238 & 0,653679 \\
\hline
\end{tabular}

Untuk menentukan tingkat keakurasian pada metode pemilihan rute keseimbangan dan all-or-nothing akan didasarkan pada perbandingan nilai uji statistik untuk masing-masing metode pemilihan rute tersebut. Hasil uji statistik pada kondisi pemilihan rute keseimbangan dan all-or-nothing adalah seperti ditunjukkan pada Tabel 8.

Dari Tabel 8 dapat dilihat bahwa jika dilakukan perbandingan antara penggunaan pemilihan rute keseimbangan dan pemilihan rute all-or-nothing, maka dari hasil uji statistik untuk tingkat arus maupun tingkat MAT, pemilihan rute keseimbangan menghasilkan kinerja yang lebih baik dalam melakukan estimasi parameter model kebutuhan transportasi. Hal tersebut bisa dilihat dari nilai koefisien determinasi $\left(\mathrm{R}^{2}\right)$. Dari sisi MAT, nilai $\mathrm{R}^{2}$ yang dihasilkan dari pemilihan rute keseimbangan adalah sebesar 0,75 sedangkan jika digunakan metode all-or-nothing, $\mathrm{R}^{2}$ yang dihasilkan adalah sebesar 0,51. Sehingga dapat diambil kesimpulan bahwa penggunaan metode pemilihan rute keseimbangan mempunyai pengaruh yang signifikan terhadap keakurasian estimasi parameter model kebutuhan transportasi. Hal tersebut berlaku untuk model GR maupun GO.

Berdasarkan faktor-faktor pengaruh yang telah disebutkan sebelumnya, kombinasi yang terbaik dalam melakukan estimasi parameter model kebutuhan transportasi adalah menggunakan: model batasan-bangkitan-tarikan, fungsi hambatan Tanner, metode estimasi KTB dan pemilihan rute keseimbangan. Secara grafis, persamaan regresi yang menghubungkan antara volume lalulintas 
hasil pengamatan $\left(\hat{\boldsymbol{V}}_{\boldsymbol{l}}\right)$ dan volume lalulintas hasil estimasi $\left(\boldsymbol{V}_{\boldsymbol{l}}\right)$ untuk masingmasing metode pemilihan rute adalah seperti ditunjukkan pada Gambar 3-4.

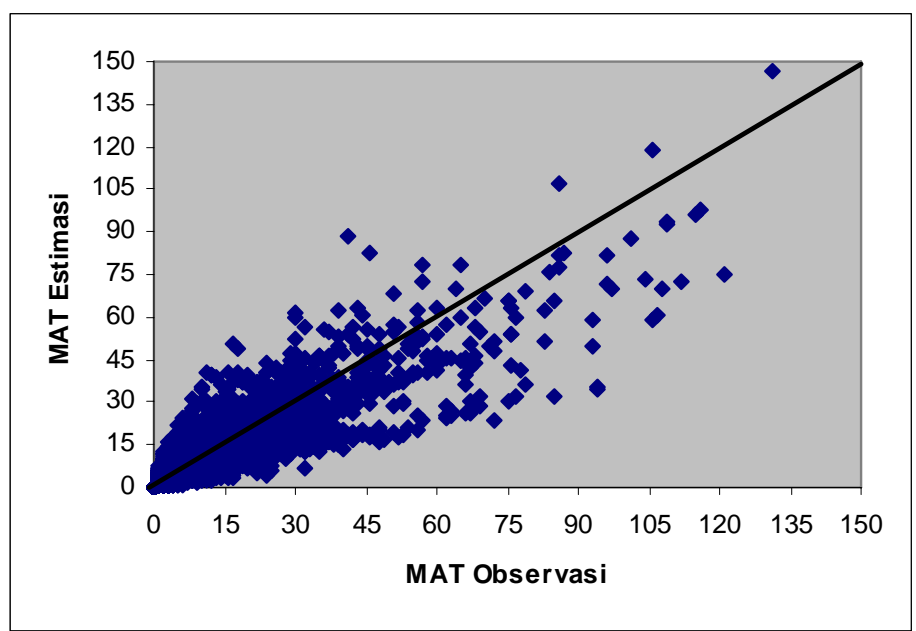

Gambar 3 Hubungan MAT hasil pengamatan dan hasil estimasi (Metode Pemilihan Rute Keseimbangan).

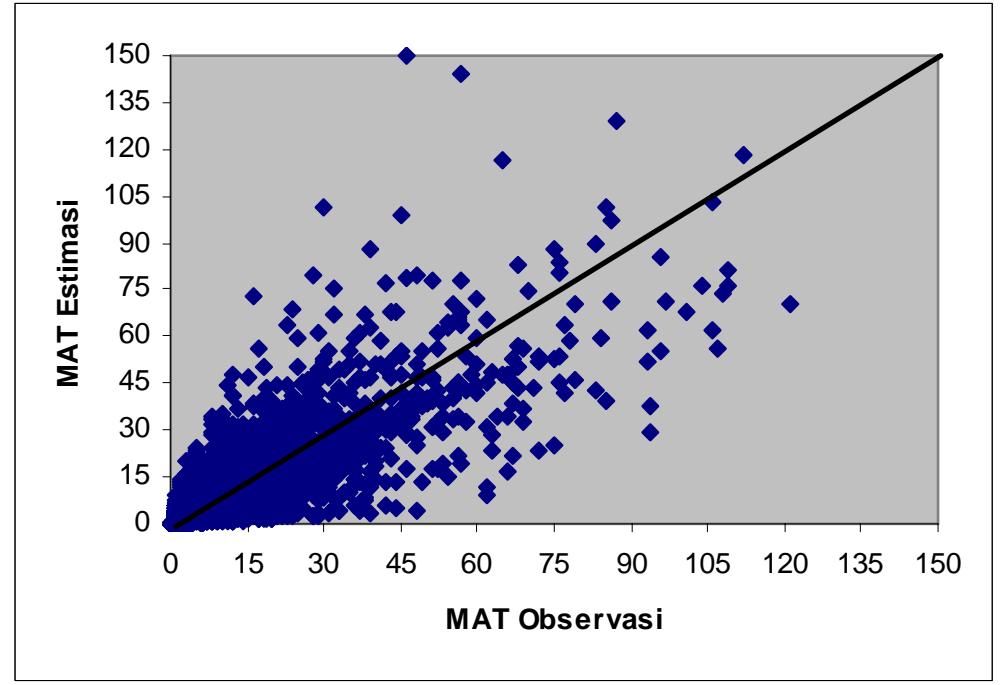

Gambar 4 Hubungan MAT Hasil Pengamatan dan Hasil Estimasi (Metode Pemilihan Rute All-Or-Nothing).

Dari Gambar 3-4 dapat dilihat bahwa penggunaan metode pemilihan rute keseimbangan mempunyai pengaruh yang sangat signifikan dalam 
meningkatkan tingkat keakurasian dalam estimasi parameter model kebutuhan transportasi.

\section{$5 \quad$ Kesimpulan dan Rekomendasi}

Penelitian ini mengkaji pengaruh model gravity terhadap akurasi perkiraan MAT berdasarkan data arus lalulintas dalam kondisi pemilihan rute keseimbangan (equilibrium assignment). Dalam kondisi tersebut nilai $p_{i d}{ }^{l}$ (proporsi pemilihan ruas jalan l untuk pergerakan dari zona $i$ ke zona $d$ ) adalah antara 0 dan 1, serta tergantung dari nilai sel-sel di dalam MAT.

Sehingga penelitian ini bertujuan untuk meninjau tingkat keakurasian MAT yang dihasilkan dari informasi data arus lalulintas yang dipengaruhi oleh faktorfaktor:

- Metode Sebaran Pergerakan "Gravity"

- Metode Estimasi Kuadrat-Terkecil (KT), Kuadrat-Terkecil-Berbobot (KTB), Kemiripan-Maksimum (KM), Inferensi-Bayes (IB), dan EntropiMaksimum (EM)

- Teknik Pemilihan Rute All-Or-Nothing dan Keseimbangan (Equilibrium Assignment)

Hasil estimasi menunjukkan bahwa proses estimasi MAT yang mempunyai tingkat kinerja terbaik adalah menggunakan: model batasan-bangkitan-tarikan, fungsi hambatan Tanner, metode estimasi KTB dan pemilihan rute keseimbangan. Hal tersebut didasarkan pada nilai hasil uji statistik dan nilai optimum dari fungsi tujuan untuk masing-masing metode estimasi.

Penelitian tahap selanjutnya diarahkan pada usaha pengembangan proses pengolahan tampilan dari keluaran MAT beserta beberapa aplikasi sehingga informatif dan mudah dimengerti (numerik maupun grafis). Pada tahap ini juga akan dirancang suatu Website yang akan digunakan sebagai tempat seluruh keluaran tersebut dapat diakses secara langsung. Termasuk juga usaha diseminasi dan sosialisasi hasil penelitian akan dilakukan dalam bentuk penyusunan manual teknis dan manual pelaksanaan yang ditindaklanjuti dengan kegiatan seminar dan pelatihan.

\section{Daftar Pustaka}

[1] Tamin, O.Z. \& Willumsen, L.G., Transport Demand Model Estimation From Traffic Counts, Journal of Transportation, UK, 1988.

[2] Tamin, O.Z., et al., Dynamic Origin-Destination (OD) Matrices Estimation From Real Time Traffic Count Information, Laporan Akhir, 
Graduate Team Research Grant, Batch IV, University Research for Graduate Education (URGE) project, 2001.

[3] Tamin, O.Z., The Estimation of Transport Demand Models From Traffic Counts, PhD Dissertation of the University of London, University College London, 1988.

[4] Tamin, O.Z., Perencanaan dan Pemodelan Transportasi, Edisi 2, Penerbit ITB, Bandung, 2000.

[5] Hyman, G.M., The Calibration of Trip Distribution Models, Environment and Planning, 1, 105-112, 1969.

[6] Suyuti, R., Estimasi Model Kebutuhan Transportasi Berdasarkan Informasi Data Arus Lalulintas Pada Kondisi Pemilihan Rute Keseimbangan, Disertasi Doktor Institut Teknologi Bandung (ITB), 2006.

[7] Tamin, O.Z., Sjafruddin, A. \& Hidayat, H., Dynamic Origin-Destination $(O-D)$ Matrices Estimation from Real Traffic Count Information, $3^{\text {rd }}$ EASTS Conference Proceeding, Taipei 15-17 September, 1999.

[8] Tamin, O.Z., et al., Dynamic Origin-Destination (OD) Matrices Estimation From Real Time Traffic Count Information, Laporan Tahap I, Graduate Team Research Grant, Batch IV, University Research for Graduate Education (URGE) project, 2000.

[9] Tamin, O.Z., Perencanaan dan Pemodelan Transportasi, Soal dan Aplikasi, Penerbit ITB, Bandung, 2003.

[10] Tamin, O.Z., Pengembangan Sistem Informasi Arus Lalulintas Sebagai Upaya Pemecahan Masalah Transportasi di Kota Bandung, Laporan Akhir Program Riset ITB, 2005.

[11] Willumsen, L.G., An Entropy Maximising Model for Estimating Trip Matrices From Traffic Counts, PhD Thesis, Department of Civil Engineering, University of Leeds, 1981. 